\title{
DECISION SUPPORT SYSTEM FOR HELP RECIPIENTS HOPE FAMILY PROGRAM ON VILLAGE WARU WITH SAW METHOD
}

\author{
Siti Nurlela1; Tuti Kurniawati²; Siti Masturoh ${ }^{3}$; Widiastuti ${ }^{4}$; Ade Suryadi ${ }^{5}$ \\ 1, 2, 3,4 Sistem Informasi \\ Sekolah Tinggi Manajemen Informatika dan Komputer Nusa Mandiri \\ www.nusamandiri.ac.id \\ siti.sie@nusamandiri.ac.id 1; tutikurniawati12@gmail.com 2; siti.uro@nusamandiri.ac.id 3 \\ widiastuti.wtu@nusamandiri.ac.id4 \\ 5Teknik dan Informatika \\ Universitas Bina Sarana Informatika \\ www.bsi.ac.id \\ ade.axd@bsi.ac.id 5
}

\begin{abstract}
Waru Village is one of the villages in the Bogor Regency area. However, the selection of recipients of the Program Keluarga Harapan (PKH) in Waru Village is still subjective/qualitative so that the process of receiving PKH in Waru Village is not accurate and has not been on target. This is what makes the need for a method that is able to manage data on recipients of the Hope Family Program (PKH) and produce a ranking from the calculation of the PKH selection weight. In making decisions about PKH recipients, there is a simple additive weighting (SAW) method that can be used in solving quantitative problems. With the SAW method, each criterion is compared to one another so as to provide $\mathrm{PKH}$ recipient results and provide an assessment of each (alternative) PKH recipient in Waru Village. This study aims to determine recipients of PKH assistance so that it can produce a decision on recipients of PKH assistance that the government distributes to the Waru village accurately on target.
\end{abstract}

Keywords: Decision Support System; Beneficiary; Program Keluarga Harapan; PKH; SAW method..

Abstrak - Desa Waru adalah salah satu desa yang berada dikawasan Kabupaten Bogor. Akan tetapi pemilihan penerima Program Keluarga Harapan (PKH) di Desa Waru masih bersifat subjektif/kualitatif sehingga pada proses penerima PKH di Desa Waru belum akurat dan belum tepat sasaran. Hal ini yang menjadikan perlunya sebuah metode yang mampu mengelola data penerima PKH dan menghasilkan ranking dari perhitungan bobot penyeleksian PKH tersebut. Dalam pengambilan keputusan penerima PKH ini, terdapat metode Simple Additive Weighting (SAW) yang dapat digunakan dalam pemecahan masalah yang bersifat kuantitatif. Denganmetode SAW masing-masing kriteria dibandingkan satu dengan yang lain sehingga memberikan hasil penerima PKH dan memberikan penilaian terhadap setiap penerima (alternatif) PKH di Desa Waru. Penelitian ini bertujuan untuk menentukan penerima bantuan PKH sehingga dapat menghasilkan sebuah keputusan penerima bantuan PKH yang disalurkan pemerintah kepada desa waru dengan akurat tepat sasaran.

Kata Kunci: Sistem Penunjang Keputusan; Penerima Bantuan; Program Keluarga Harapan; PKH; Metode SAW.

\section{INTRODUCTION}

By article 27 paragraph 2, every citizen has the right to work and to get a life that is worthy of humanity (Undang-Undang Dasar Negara Republik Indonesia 1945, 2016). Therefore, every citizen has the right to get a decent life. Through the government assistance program for the poor, in the form of APBN, APBD, BLT, RASKIN, house renovation, and family latrines, it is hoped that it can help the difficulties experienced by residents at this time.

Currently, the unemployment rate in Indonesia is still high. unemployment in the city of Bogor has increased significantly every year (Hanifah, Pratidina, \& Seran, 2018) The high unemployment rate in Bogor City has a direct impact on the poverty rate. Poverty is one of the fundamental problems in a region. (Adawiya, 2020) The reason is, even though it has decreased, but when compared to Depok City, the poverty rate in the City of Bogor is still quite high, especially if Bogor City is not an industrial city. (Hanifah et al., 2018) One of the villages in Bogor with a poverty rate that is quite influencing the high level of poverty in the city of Bogor is Waru village which is in the Parung-Bogor sub-district. 
Government programs in beating the monetary emergency that has happened so far by giving direct help to Keluarga Sangat Miskin (KSM), conditional social assistance program to Keluarga Penerima Manfaat (KPM) (Pratiwi, Ferdinandus, \& Limantara, 2019) in every village throughout Indonesia. Program Keluarga Harapan or what is often referred to as PKH (Prabowo \& Prasetyo, 2020) PKH is one of the programs that is integrated between health and social and PKH provides conditional cash assistance to Very Poor Households (Ninditama, Robinson, \& Widji, 2020) which of course examines the lives of the more broad organization including destitute individuals. However, the results of the analysis are expected to obtain what is not yet accurate, other than that it is still assessed to be inaccurate (Pratiwi et al., 2019). This is what makes researchers make research in Waru Village using the SAW method (Guswandi, 2017).

Table 1. Research Literature

\begin{tabular}{ll}
\hline Research Problem \\
RP1 & $\begin{array}{l}\text { Determination of recipients of assistance } \\
\text { from the hopeful family program is accurate } \\
\text { and not on target }\end{array}$ \\
\hline
\end{tabular}

Literature Support

The results of the analysis are inaccurate, apart from that it is still considered not on target (Pratiwi et al., 2019).

Using the AHP-TOPSIS method, the biggest decision result is A4 0.585 . (Irawan, 2020)

To get higher decision results, the decision making in this study uses the The use of methods in making decisions to Simple Additive Weighting (SAW) receive assistance from PKH has not got the method. (Sukerti, 2014)

RP2 best results by comparing the criteria and alternatives that have been determined

The SAW method determines a decision by choosing from a variety of alternatives (Sholinka, 2020)

Besides having the ability to compare the SAW method criteria, the SAW method requires the decision-maker to determine the weight for each attribute (Yulianti \& Wati, 2019).

The simple additive weighting method simplifies the process of determining the prospective family program candidates according to the criteria and right on target

RP3 decisions accurately and on target.

(Purnia, Lena, \& Ratningsih, 2019)

The SAW method is also suitable to be implemented for decisions in making choices (Salim, 2018)

This method is suitable for accurate calculations and is very helpful in calculating any data obtained (Pahu, 2018).

Source : (Nurlela, Kurniawati, Masturoh, Widiastuti, \& Suryadi, 2020)

This study aims to determine recipients of assistance with the family hope program by utilizing a DSS and the SAW method by determining criteria and alternatives to produce a recipient decision for $\mathrm{PKH}$ assistance that is channeled by the government to Waru village accurately and on target.

\section{MATERIALS AND METHODS}

\section{Research Stage}

In this research, there are several steps to determine the recipient of the expected family assistance. The stages are as follows: 


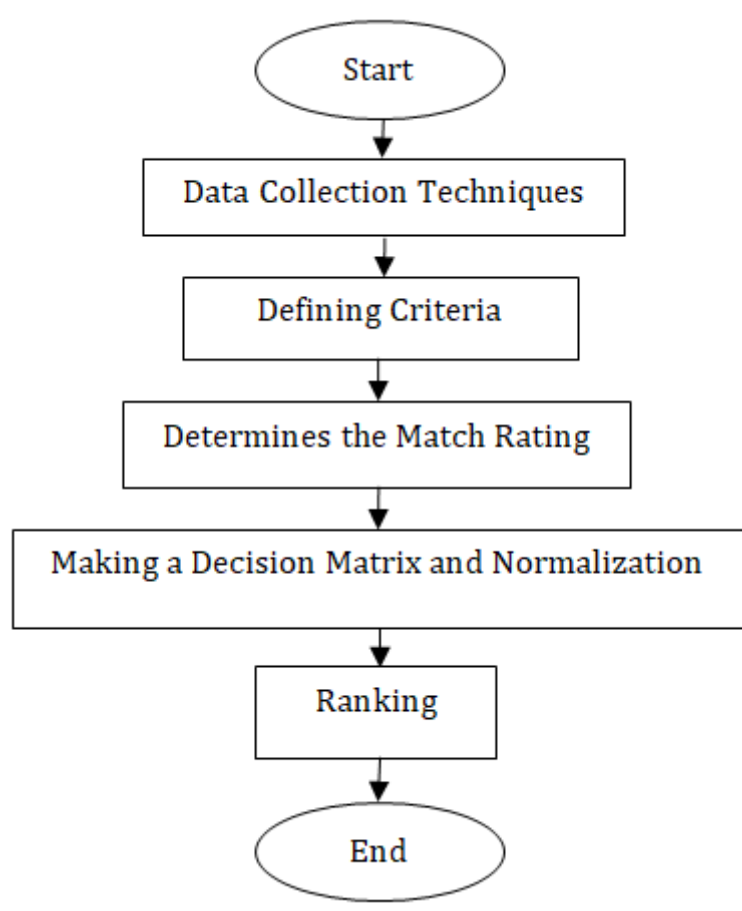

Source : (Nurlela et al., 2020)

Picture 1. Research Stage

The research stage carried out in this study began with data collection techniques by distributing questionnaires to respondents, observation, interviews, and literature studies. The next stage determines what criteria will be used as a reference in determining recipients of $\mathrm{PKH}$ assistance. Next, decide the reasonableness rating of every option on every basis. At that point continue with settling on a choice network shaped from the reasonableness rating table of every option on every rule and information standardization, then the ranking stage. This ranking stage will determine which alternatives are selected in determining the recipients of the Family Hope Program (PKH) assistance.

\section{Data Collection Technioques}

The data collection method used in determining the Beneficiary of PKH is as follows:

\section{Questionnaire}

At this stage, questionnaires were distributed to all Waru Village officials, from a total of 53 Waru Village officials, the writer determined 49 questionnaires distributed with an error rate of $1 \%$ and the questionnaires that had been answered by respondents would become data that would later be processed. This research was taken from Waru Village and the research subjects were Waru Village officials who would fill out the questionnaire, while the total apparatus of Waru Village was 53 employees who were grouped into Honorary employees and State employees. And the objects of this research are residents who are recipients of PKH funds in Waru Village.

The sample used in this study is the random sampling technique. In this case, the sample is randomized without paying attention to strata, where all Waru Village apparatus from all sections can fill out the research questionnaire. The number of samples in this study (Sugiyono, 2016) in the table for determining the number of samples, from a certain population with an error rate of $1 \%, 5 \%$, and $10 \%$. In this study, the total population of 53 , the sample was taken was 49 with an error rate of $1 \%$.

\section{Observation}

At the observation stage, direct observations were made to Waru Village and asked for data from you. Mohamad Mansyur as Secretary of Waru Village. The data needed in this study are data on recipients of PKH grant.

\section{Interview}

The interview conducted by the researcher was in the form of a question and answer activity to Bpk. Soni Sunandi, a PKH assistant at Waru Village. The author asks about PKH funds and the ongoing process of receiving and $\mathrm{PKH}$ in Waru Village which is still quantitative.

\section{Literature Review}

At this stage, the researcher conducts a literature study by studying reference books and journals related to this research.

\section{RESULTS AND DISCUSSION}

In processing the research results, the writer determines the steps for completion by the Simple Additive Weight (SAW) steps where there are four steps, namely determining the criteria to be used as a reference, determining the suitability rating of each alternative on each criterion, making a decision matrix and ranking.

\section{Defining Criteria}

The stages determine the criteria used in selecting an alternative and solving complex or unstructured problems into sub-problems and then arranging them into a hierarchy. In this hierarchy, it is made into 3 parts, namely objectives, criteria, and alternatives. 


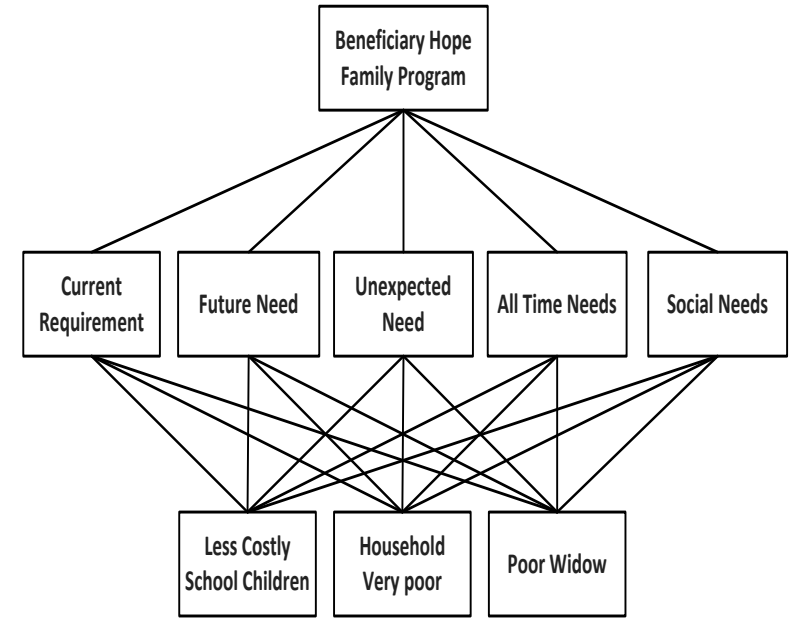

Source : (Nurlela et al., 2020)

Picture 2. Hierarchy of Grant Recipients for the Family Hope Program

At this stage, a hierarchy of funding for the family hope program assistance is made with 5 criteria, namely:
a. Current Requirement
b. Future Need
c. Unexpected Need
d. All Time Needs
e. Social Needs

The alternatives used in the hierarchy of receiving funds from the family hope program assistance are 3 , including:

a. Less Costly School Children

b. Household Very poor

c. Poor Widow

Table 2. Values and Weights for Criteria

\begin{tabular}{cl}
\hline \multicolumn{2}{c}{$\mathrm{C} 1, \mathrm{C} 2, \mathrm{C} 3, \mathrm{C} 4$, and C5 } \\
\cline { 1 - 2 } Values & Information Weights \\
\hline Weights & \\
\hline 5 & Very Good \\
\hline 4 & Good \\
\hline 3 & Enough \\
\hline 2 & Bad \\
\hline 1 & Very Bad \\
\hline
\end{tabular}

Source : (Nurlela et al., 2020)

The weights used in selecting recipients of PKH assistance funds are as follows:

$\begin{array}{ll}\text { C1 }=\text { Current Requirement } & : \text { Verry Good } \\ \text { C2 }=\text { Future Need } & : \text { Verry Good } \\ \text { C3 }=\text { Unexpected Need } & : \text { Good } \\ \text { C4 }=\text { All Time Needs } & : \text { Good } \\ \text { C5 }=\text { Social Needs } & \text { : Enought }\end{array}$

The weighting for each criterion is $\mathrm{C} 1=5$, $\mathrm{C} 2=4, \mathrm{C} 3=3, \mathrm{C} 4=2, \mathrm{C} 5=1$. The weight of each criterion is as follows:

Table 3. Criteria Weights

\begin{tabular}{cll}
\hline No & \multicolumn{1}{c}{ Criteria } & Weights \\
\hline 1 & Current Requirement & 0,30 \\
\hline 2 & Future Need & 0,25 \\
\hline 3 & Unexpected Need & 0,20 \\
\hline 4 & All Time Needs & 0,15 \\
\hline 5 & Social Needs & 0,10
\end{tabular}

Source : (Nurlela et al., 2020)

\section{Determines the Match Rating}

The second step in determining the recipients of the expected family program assistance is deciding the fittingness rating of each alternative on each standard. The determination of the match rating is as follows:

Tabel 4. Match Rating

\begin{tabular}{cccccc}
\hline \multirow{2}{*}{ Alternative } & \multicolumn{5}{c}{ Research Result } \\
\cline { 2 - 6 } & C1 & C2 & C3 & C4 & C5 \\
\hline A1 & 4 & 3 & 2 & 3 & 3 \\
\hline A2 & 4 & 4 & 3 & 4 & 4 \\
\hline A3 & 4 & 3 & 3 & 4 & 3 \\
\hline
\end{tabular}

Source : (Nurlela et al., 2020)

\section{Making a Decision Matrix and Normalization}

After the elective rating esteem is discovered, the third step is the arrangement of a choice Matrix (x) which is framed from the appropriateness rating table of every option on every measure. Settling on a choice grid dependent on the criteria (Ci), at that point normalizing the framework dependent on the condition that is acclimated to the sort of quality (benefit characteristic or cost trait) to get a standardized Matrix R.

$$
\begin{array}{lllll}
\mathbf{4} & \mathbf{3} & \mathbf{2} & \mathbf{3} & \mathbf{3} \\
\mathbf{4} & \mathbf{4} & \mathbf{3} & \mathbf{4} & \mathbf{4} \\
\mathbf{4} & \mathbf{3} & \mathbf{3} & \mathbf{4} & \mathbf{3}
\end{array}
$$

Next, calculate the normalized value of each alternative to get the normalization matrix clan. The calculation uses the normalization formula, where the normalization results are made in the normalization matrix, while the normalization matrix of this study is as follows:
$1,00 \quad 1,00 \quad 1,00 \quad 1,00 \quad 1,00$
$1,00 \quad 0,75 \quad 0,66 \quad 0,75 \quad 0,75$
$1,00 \quad 1,00 \quad 0,66 \quad 0,75 \quad 1,00$ 


\section{Ranking}

The fourth step is to calculate the final result of the preference value (Vi) obtained from the sum of the normalized matrix row element multiplication $(\mathrm{R})$ with the preference weight $(\mathrm{W})$. the weights used are as follows:

$$
W=0,30 \quad 0,25 \quad 0,200,15 \quad 0,10
$$

The results of the above calculations can be concluded that the results are with the Vi value rank from the smallest value so that the best alternative is to determine the recipients of $\mathrm{PKH}$ assistance in Waru Village based on the highest value found in this Table 5 :

Table 5. Ranking

\begin{tabular}{clcccc}
\hline No & Alternative & The Result & The Final Result & Percentage & Ranking \\
\hline $\begin{array}{l}\text { Less Costly } \\
1\end{array}$ & Children & 1,00 & 0,370164723 & $37 \%$ & 1 \\
\hline 2 & Household Very poor & 0,807 & 0,298722932 & $30 \%$ & 3 \\
\hline 3 & Poor Widow & 0,8945 & 0,331112345 & $33 \%$ & 2 \\
\hline Amount & 2,7015 & 1 & $100 \%$ & \\
\hline
\end{tabular}

Source : (Nurlela et al., 2020)

The decision results obtained are based on calculations using the Simple Additive Weighting method with a total sample size of 49 samples from the Waru village apparatus and using 5 criteria. Current needs (C1), future needs (C2), unexpected needs (C3), needs all the time (C4), and health needs or dependents (C5). The alternative for school children is less cost (v1), very poor households (v2) and poor widows (V3) get the biggest result is V1 so that the chosen alternative is accurate and right on target and has the right to receive assistance from $\mathrm{PKH}$ in Waru Village is $\mathrm{V} 1=$ Less costly school children with a decision result of 1.00 and a percentage of $37 \%$.

\section{CONCLUSION}

In view of the examination led by the creator, it tends to be reasoned that to decide Waru Village Family Hope Program (PKH) Recipients can use quantitative data such as Current Needs, Future Needs, Unexpected Needs, All Time Needs, and Health Needs or dependents of each of the prospective recipients of the family hope program, namely: Less Costly School Children, Very Poor Households and Poor Widows. Calculations carried out in this study to determine the recipients of the Waru Village PKH can use the Simple Additive Weight method, so one prospective recipient is selected who will be the recipient of $\mathrm{PKH}$, namely school children less cost (V1). The decision result obtained is 1.00 with a percentage of $37 \%$.

\section{REFERENCE}

Adawiya, R. (2020). Analisis Pengaruh Tingkat Pendidikan Dan Pengangguran Terhadap Jumlah Penduduk Miskin Kabupaten Bogor
Tahun 2015 Di Parung. Al Amin: Jurnal Kajian Ilmu Dan Budaya Islam, 3(1), 19-35. Retrieved from http://stitalamin.ac.id/jurnal/index.php/ala $\mathrm{min} /$ article/view/38

Guswandi, D. (2017). Sistem Pendukung Keputusan Bantuan Bedah Rumah Menggunakan Metode Simple Additive Weighting Pada Badan Amil Zakat. Majalah Ilmiah, 24(1), 221-234.

Hanifah, I., Pratidina, G., \& Seran, M. Y. (2018). Kinerja Dinas Tenaga Kerja Dan Transmigrasi Dalam Melaksanakan Program Pengurangan Angka Pengangguran. Jurnal Governansi, 4(1), 11. https://doi.org/10.30997/jgs.v4i1.1136

Irawan, F. (2020). Sistem Penunjang Keputusa Sistem Pendukung Keputusan Penerima Program Keluarga Harapan (PKH) Menggunakan Metode AHP Dan TOPSIS (Studi Kasus: Kelurahan Sribasuki Kotabumi). Aisyah Journal of Informatics and Electrical Engineering (A.J.I.E.E), 2(2), 171178. Retrieved from http://jti.aisyahuniversity.ac.id/index.php/AJ IEE/issue/view/3

Ninditama, I. P., Robinson, R., \& Widji, T. (2020). Sistem Pendukung Keputusan Penerima Program Keluarga Harapan (Pkh)Dengan Menggunakan Metode Simple Additive Weighting (SAW) Di Kecamatan Ilir Barat II Palembang. Jurnal Sistem Informasi (JASISFO), 1(1), 11-21. Retrieved from https://jurnal.polsri.ac.id/index.php/jasisfo/ article/view/1954

Nurlela, S., Kurniawati, T., Masturoh, S., Widiastuti, W., \& Suryadi, A. (2020). Laporan Akhir 
Penelitian: Sistem Pendukung Keputusan Penerima Bantuan Program Keluarga Harapan Pada Desa Waru Dengan Metode SAW. Jakarta.

Pahu, G. Y. K. S. S. (2018). Sistem Pendukung Keputusan Untuk Menyeleksi Penerima Dana Bantuan Siswa Miskin Menggunakan Metode Simple Additive Weighting (SAW). EXPERT, 8(2), 83-88. Retrieved from http://jurnal.ubl.ac.id/index.php/expert/arti cle/view/1116

Prabowo, D., \& Prasetyo, B. H. (2020). Pemilihan Warga Penerima Bantuan Program Keluarga Harapan ( $P K H$ ) Menggunakan Metode Simple Additive Weighting ( $S A W$ ) dan User Acceptance Testing (UAT ). 5(3), 379-386.

Pratiwi, I. P., Ferdinandus, F., \& Limantara, A. D. (2019). Sistem Pendukung Keputusan Penerima Program Keluarga Harapan (PKH) Menggunakan Metode Simple Additive Weighting. Jurnal Teknik Informatika, Sistem Informasi, Dan Ilmu Komputer, 8(2), 182-195.

Purnia, D. S., Lena, L., \& Ratningsih, R. (2019). Sistem Informasi Penentuan Calon PKH Menggunakan Metode SAW (Studi Kasus PPKH Kab.Tasikmalaya). Indonesian Journal on Software Engineering (IJSE), 5(2), 135148. https://doi.org/10.31294/ijse.v5i2.7154
Salim, M. A. (2018). Sistem Pendukung Keputusan Pemilihan Penerima Bantuan Perbaikan Rumah Menggunakan Metode Simple Additive Wieghting (SAW) Studi Kasus Kelurahan Tambelan Sampit Kota Pontianak. Jurnal SISTEMASI, 7(2), 120-131.

Sholinka, A. (2020). Sistem Pendukung Keputusan Penerima Bantuan Sosial Menggunakan Metode Simple Additive Weighting (Studi Kasus: Ketimbang Ngemis Yogyakarta) (Universitas Teknologi Yogyakarta). Universitas Teknologi Yogyakarta. Retrieved from http://eprints.uty.ac.id/5801/

Sugiyono. (2016). Metode Penelitian Kuantitatif, Kualitatif, dan R\&D (Alfabeta, Ed.). Bandung.

Sukerti, N. K. (2014). "Sistem Penunjang Keputusan Penerima Bantuan Desa dengan Metode SAW." Jurnal Informatika, 14(SPK), 84-92.

Undang-Undang Dasar Negara Republik Indonesia 1945. (2016). Jakarta: DPR RI. Retrieved from http://www.dpr.go.id/jdih/uu1945

Yulianti, E., \& Wati, S. (2019). Sistem Pendukung Keputusan Pemilihan Penerima Program Keluarga Harapan Menggunakan Metode Simple Additive Weighting (SAW). Jurnal TEKNOIF, 7(1), 40-47. https://doi.org/10.47047/ct.v8i2.46 